\title{
Foam-mat Drying of Carrot Juice and Thin Layer Modeling of Drying
}

\author{
Hulya Cakmak ${ }^{1}$ Vasfiye Hazal Ozyurt ${ }^{2}$ \\ ${ }^{1}$ Hitit University, Department of Food Engineering, Corum, Turkey \\ ${ }^{2}$ Mugla Sitki Kocman University, Department of Gastronomy and Culinary Arts, Mugla, Turkey
}

\begin{abstract}
ABS T R ACT
$\mathrm{D}$ rying of fruit and vegetables is critical step of processing which can be very destructive for nutrients and especially for bioactive compounds. However, novel drying methods like foam-mat drying helps to decrease the drying period and exposure to drying air therefore protect the bioactives against thermal degradation as well as improving final powder quality. The foam-mat drying of carrot juice and modeling of experimental drying data with the theoretical models has not yet been studied in the literature. In this study, the effects of foam-mat drying at 50,60 and $70^{\circ} \mathrm{C}$ on the drying behavior of carrot juice with the addition of $15 \%$ egg albumen (EA) and $15 \%$ egg albumen+ $10 \%$ whey protein isolate (WPI) as foaming agents and thin-layer modeling of the foams at different thicknesses were evaluated. Compared to the control sample (only carrot juice), the drying time of the foamed carrot juice was reduced by $25 \%$ to $60 \%$ depending on the foam thickness and drying temperature. These results were consistent with the effective diffusion coefficients $\left(\mathrm{D}_{\text {eff }}\right)$, since the control sample had comparably low $\mathrm{D}_{\text {eff }}$ value than the $15 \%$ EA and $15 \%$ EA $+10 \%$ WPI foams. Among the fitted mathematical models, Midilli et al. had better prediction capacity with the highest adjusted correlation coefficients, in addition to the lowest sum of squared error and root mean square error values for every formulation, foam thicknesses and drying temperatures compared to other theoretical models.
\end{abstract}

Keywords:

Carrot juice; Foam-mat drying; Modeling; Thin-layer

\section{INTRODUCTION}

F resh fruits and vegetables are highly perishable - because of their high moisture content and should be consumed without any deterioration if only stored properly or food preservation methods such as; freezing, canning, chemical treatments, or drying are employed for increasing their shelf life [1].

Drying is one of the oldest food preservation methods used because it increases the shelf-life of foodstuffs by reducing the water activity, therefore the dried products can be stored for later use. Besides, microbial activity that is causing the spoilage of the food is prevented, and at the same time, most of enzymes that is evoking chemical changes in the food cannot perform their functions due to moisture removal. Thus, dried foods can be stored for a longer period [2].

Drying methods using hot air with natural or forced convection are mostly preferred for drying foods. However, since the chosen method is effective on the quality characteristics of the final product, drying methods such as; contact drying [3], convective drying [4], radiation drying [5], freeze-drying [6], osmotic drying [7] are used for drying of agricultural products like; vegetables, fruits, and cereals. Alternative drying methods are constantly being developed, since the quality of the final product is important. Foam-mat drying is a novel technique developed to increase the moisture transfer during the drying of liquid and semi-liquid foods. The foam-mat drying process, which is carried out by the addition of foaming agents and stabilizers, has come to the forefront due to its advantages such as shortening the drying time with hot air, and better preservation of the dried food quality, and many studies have been carried out on foam drying [8]. The drying of agricultural products using foam drying methods has been studied by many researchers. In these studies, vegetable and fruits such as; instant yam (Dioscorea rotundata) [9], banana [10], tomato pulp [11], blackcurrant pulp [12], papaya nectar [13], mango [14], muskmelon [15], yacon juice [16] 
and crab apple juice [8] were dried by this method. Although there are a few studies about carrot powder production with foam-mat drying by incorporation of some other foaming agents like Tween 80, methylcellulose and egg white, these studies mostly focused on chemical composition of the powders or powder yield [17, 18]. Moreover, the foammat drying of carrot juice including different animal-based protein sources as foaming agents and the mathematical modeling of drying has not been studied yet. Therefore, the objective of this study was to determine the drying behavior of carrot juice by foam-mat drying method and mathematical modeling of the experimental drying data by exploring the presence of egg albumen (EA) and egg albumen + whey protein isolate (WPI) in the formulation together with the foam thickness at different drying temperatures.

\section{MATERIALS AND METHODS}

Fresh carrots and whole eggs were purchased from a local supermarket in Corum, Turkey. Whey protein isolate with $96 \%$ protein was supplied from local distributor of Hipro Iso whey (Bionet Tic. A.S., Istanbul).

Fresh carrot juice was extracted according to the previous study of Cakmak and Ozyurt [19]. The extracted juice were filled into the glass bottles and heat-treated at $95^{\circ} \mathrm{C}$ for 5 min [20] in a water bath (Wise Bath, WB22, Daihan Scientific, South Korea), and cooled to $4^{\circ} \mathrm{C}$.

\section{Production of Carrot Juice Foams}

The most stable foam structure was obtained from the $15 \%$ EA+10\% WPI foam formulation according to the previous study of the authors which was mixed at the highest speed with a hand-blender (Arzum Pasto AR-183, Turkey) for $8 \mathrm{~min}$ whipping time. In addition to this formulation, 15\% EA including foams were prepared similarly to the given foaming conditions.

\section{Thin Layer Drying of Carrot Juice Foams}

15\% EA and 15\% EA+ 10\% WPI foams together with control (carrot juice without foaming) were spread evenly on petri dishes (OD: $90 \mathrm{~mm}$ ) at two different thicknesses, in order to equilibrate the mass on each petri dishes. For control, the samples were placed with the thickness of 2.5 and $3.2 \mathrm{~mm}$, whereas 15\% EA and 15\% EA+ 10\% WPI including foams the thickness was arranged as 5 and $6 \mathrm{~mm}$. The samples were dried at 50,60 and $70^{\circ} \mathrm{C}$ in a preheated built-in oven (Model no: NV60K7140BB, Samsung, Turkey) with upper-lower heating function at $0.9 \mathrm{~m} / \mathrm{s}$ steady air velocity until constant weight was observed. Drying experiments performed at least five parallels and the mass of petri dishes were recorded with an analytical ba-
Table 1. Thin layer models fitted to experimental drying datas.

\begin{tabular}{ccc} 
Model & Model eq. & Reference \\
Lewis & $M R=e^{(-k t)}$ & {$[8],[21]$} \\
Page & $M R=e^{\left(-k t^{n}\right)}$ & {$[8],[21]$} \\
Henderson \& Pabis & $M R=a e^{(-k t)}$ & {$[8],[21]$} \\
Logarithmic & $M R=a e^{(-k t)}+c$ & {$[8],[21]$} \\
Two-term & $M R=a e^{\left(-k_{0} t\right)}+b e^{\left(-\mathrm{k}_{1} \mathrm{t}\right)}$ & {$[8],[21]$} \\
Midilli et al. & $M R=a e^{\left(-k t^{n}\right)}+b t$ & {$[8],[21]$} \\
Modified Midilliet al. & $M R=e^{\left(-k t^{n}\right)}+b t$ & {$[8],[21]$} \\
\hline
\end{tabular}

lance (Precisa Gravimetrics, XB220A, Switzerland) every $10 \mathrm{~min}$ for first half hour, and every $30 \mathrm{~min}$ until the constant weight was observed. The drying curves of the samples were obtained from the plot of drying rate $(\mathrm{kg}$ water/ $\mathrm{hm}^{2}$ ) versus free moisture content ( $\mathrm{kg}$ water/ $\mathrm{kg}$ dry solid) with respect to the removed free water during aforementioned time intervals at constant surface area exposed during drying.

\section{Mathematical Modeling of Foam-mat Drying}

Fick's second law of diffusion was employed for evaluation of the moisture transfer from the control and carrot juice foam samples. The diffusion equation for an infinite slab at falling rate drying period is given in Eq.1;

$$
\begin{aligned}
& M R=\frac{M-M_{e}}{M_{0}-M_{e}} \\
& =\frac{8}{\pi^{2}} \sum_{n=0}^{\infty} \frac{1}{(2 \mathrm{n}+1)^{2}} \exp \left[-(2 \mathrm{n}+1)^{2} \frac{\pi^{2}}{4} \frac{D_{e f f}}{L^{2}}\right]
\end{aligned}
$$

here MR shows the dimensionless moisture ratio, $M_{0}$ is initial moisture and $M_{e}$ is the equilibrium moisture content. $M$ represents the moisture at any time $t, L$ is the thickness of the slab in $\mathrm{m}$, and $D_{\text {eff }}$ represents effective diffusion coefficient $\left(\mathrm{m}^{2} / \mathrm{s}\right)$.

The experimental drying data of the control and carrot juice foams were fitted to the thin layer models given in Table 1 by using Matlab R2016A (MathWorks Inc., USA). The goodness of model fit was evaluated with respect to the Adj- $\mathrm{R}^{2}$ (adjusted correlation coefficient), SSE (sum of squared error) and RMSE (root mean square error) values.

\section{RESULTS AND DISCUSSION}

The drying rate curves of the samples are shown Fig. 1a, $1 \mathrm{~b}$ and $1 \mathrm{c}$ for drying at 50,60 and $70^{\circ} \mathrm{C}$ together with the lowest foam thicknesses (for control: $2.5 \mathrm{~mm}$, for 15\% EA and 15\% EA + 10\% WPI: $5 \mathrm{~mm}$ ), respectively. It is seen that the control sample and 15\% EA foam had both constant and falling rate period at all drying temperatures. In addition, it was observed that the $15 \% \mathrm{EA}+10 \% \mathrm{WPI}$ 

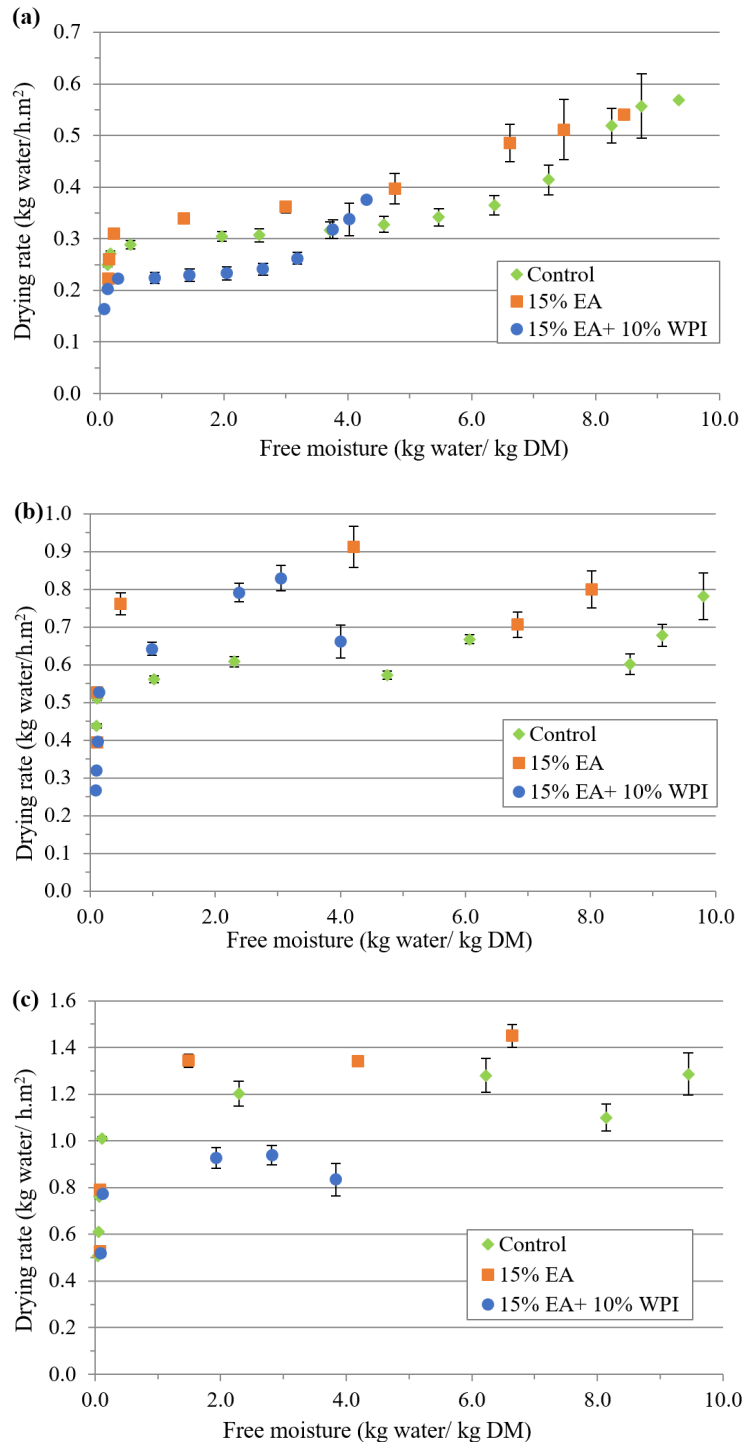

Figure 1. Drying rate curves of carrot juice (control), $15 \% \mathrm{EA}$ and $15 \% \mathrm{EA}+10 \%$ WPI foams at (a) $50^{\circ} \mathrm{C}$, (b) $60^{\circ} \mathrm{C}$ and (c) $70^{\circ} \mathrm{C}$, respectively.

sample had both constant and falling rate period only at $50^{\circ} \mathrm{C}$, and only falling rate period at 60 and $70^{\circ} \mathrm{C}$. Besides, the increase in drying temperature increased the drying rate by accelerating the moisture transfer at the elevated temperatures. The initial moisture content of control sample was reduced from $9.965 \mathrm{~kg}$ water/ $\mathrm{kg}$ DM to 0.125 $\mathrm{kg}$ water $/ \mathrm{kg} \mathrm{DM}$ at $50^{\circ} \mathrm{C}$, to $0.111 \mathrm{~kg}$ water/ $\mathrm{kg} \mathrm{DM}$ at $60^{\circ} \mathrm{C}$ and to $0.047 \mathrm{~kg}$ water $/ \mathrm{kg} \mathrm{DM}$ at $70^{\circ} \mathrm{C}$ for $2.5 \mathrm{~mm}$ thickness. Besides, the initial moisture content of 15\% EA foam was reduced from $9.542 \mathrm{~kg}$ water/ $\mathrm{kg}$ DM to $0.151 \mathrm{~kg}$ water/ kg DM, $0.105 \mathrm{~kg}$ water/ kg DM, $0.078 \mathrm{~kg}$ water $/ \mathrm{kg}$ $\mathrm{DM}$ for drying at 50,60 and $70^{\circ} \mathrm{C}$, respectively.

Drying period of the samples reaching the constant weight was found dependent on the drying temperature. For $50^{\circ} \mathrm{C}$, the drying period was observed between $360-480 \mathrm{~min}$ for control sample, whereas it was between 210-240 min for
15\% EA foam and between 240-270 min for 15\% EA+ 10\% WPI at both thicknesses. Similarly, the drying period at $70^{\circ} \mathrm{C}$ lasted $150 \mathrm{~min}$ for the control sample; while the drying period of 15\% EA sample was $90 \mathrm{~min}$ and $60 \mathrm{~min}$ for the 15\% EA $+10 \%$ WPI sample at both thicknesses. As can be seen from these observations, the foam-mat drying method shortened the drying time by $25-60 \%$ depending on the drying temperature and the foam thickness (amount).

The effective diffusion coefficients are influenced by the drying temperature, although the foam viscosity may hinder the moisture transfer [22]. The $D_{\text {eff }}$ of the control sample was found between $9.403 \times 10^{-9}-9.803 \times 10^{-8} \mathrm{~m}^{2} / \mathrm{s}$, for $15 \%$ EA it was between 1.421-6.262 $\times 10^{-7} \mathrm{~m}^{2} / \mathrm{s}$ and for $15 \%$ EA+ $10 \%$ WPI foam it was between $5.499 \times 10^{-8}-5.990 \times 10^{-7}$ $\mathrm{m}^{2} / \mathrm{s}$, respectively. In accordance with the drying period values, foam-mat drying improved the moisture diffusion compared to control sample due to increased water-air interface area due to foaming $[8,22,23]$.

The results of regression analysis employed for finding the best thin layer model representing the foam-mat drying of carrot juice foams are given in Table 2, 3 and 4. The Adj- $\mathrm{R}^{2}$ values of the tested mathematical models were found between 0.93-0.99 and very successful in terms of representing the experimental drying data of carrot juice and foams at any drying temperature and foam thickness. But the most successful model was determined as Midilli et al. with the highest Adj- $\mathrm{R}^{2}$ together with the lowest SSE and RMSE values. The model constants of Midilli et al. model are also shown in Table 5.

Foam-mat drying offers several advantages like increasing the moisture transfer rate by increasing the air-water interface due to volume expansion via foaming. Thus, this method decreases the energy consumption, improves reconstitution capacities of produced powders thus product quality, as well as protecting the bioactive compounds against thermal degradation compared to the conventional drying methods by encapsulation like mechanism of the proteins [8], [24], [25], [26].

Similar to the present study, the foam-mat drying reduced the drying period of apple juice [24], mango puree [23], crab apple juice [8] and date puree [27].

The effective diffusion coefficients can be affected from the foam formulation and the drying temperature [23], and increasing the drying temperature increases the $D_{\text {eff }}$ values because of faster moisture transfer from the material [26]. Chaux-Gutiérrez et al. [23] stated in their study that the $D_{\text {eff }}$ values of foam-mat drying of mango pulp was found between $2.15-6.12 \times 10^{-10} \mathrm{~m}^{2} / \mathrm{s}$, whereas the $D_{\text {eff }}$ values of lime juice foams $8.980 \times 10^{-9}$ and $1.138 \times 10^{-8} \mathrm{~m}^{2} / \mathrm{s}$ [22]. These values are in accordance with the $D_{\text {eff }}$ values of carrot juice foams. 
Table 2. Statistical results of tested models for drying at $50^{\circ} \mathrm{C}$.

\begin{tabular}{|c|c|c|c|c|}
\hline Sample- thickness & Model & Adj- $R^{2}$ & SSE & RMSE \\
\hline \multirow{7}{*}{ Control-2.5 mm } & Lewis & 0.9657 & 0.05653 & 0.06595 \\
\hline & Page & 0.9794 & 0.03130 & 0.05107 \\
\hline & Henderson \& Pabis & 0.9642 & 0.05438 & 0.06732 \\
\hline & Logarithmic & 0.9642 & 0.05438 & 0.06732 \\
\hline & Two-term & 0.9570 & 0.05442 & 0.07377 \\
\hline & Midilli et al. & 0.9846 & 0.02147 & 0.04418 \\
\hline & Modified Midilli et al. & 0.9794 & 0.03130 & 0.05107 \\
\hline \multirow{7}{*}{ Control-3.2 mm } & Lewis & 0.9427 & 0.09119 & 0.08071 \\
\hline & Page & 0.9692 & 0.04551 & 0.05916 \\
\hline & Henderson \& Pabis & 0.9421 & 0.08560 & 0.08115 \\
\hline & Logarithmic & 0.9421 & 0.08560 & 0.08115 \\
\hline & Two-term & 0.9316 & 0.08561 & 0.08822 \\
\hline & Midilli et al. & 0.9819 & 0.02672 & 0.04534 \\
\hline & Modified Midilli et al. & 0.9735 & 0.03917 & 0.05489 \\
\hline \multirow{7}{*}{$15 \% E A-5 \mathrm{~mm}$} & Lewis & 0.9781 & 0.03021 & 0.05793 \\
\hline & Page & 0.9888 & 0.01378 & 0.04150 \\
\hline & Henderson \& Pabis & 0.9780 & 0.02699 & 0.05808 \\
\hline & Logarithmic & 0.9780 & 0.02699 & 0.05810 \\
\hline & Two-term & 0.9706 & 0.02699 & 0.06707 \\
\hline & Midilli et al. & 0.9888 & 0.01204 & 0.04147 \\
\hline & Modified Midilli et al. & 0.9888 & 0.01378 & 0.04150 \\
\hline \multirow{7}{*}{$15 \% E A-6 m m$} & Lewis & 0.9781 & 0.03021 & 0.05790 \\
\hline & Page & 0.9872 & 0.01564 & 0.04421 \\
\hline & Henderson \& Pabis & 0.9709 & 0.03570 & 0.06680 \\
\hline & Logarithmic & 0.9780 & 0.02699 & 0.05808 \\
\hline & Two-term & 0.9706 & 0.02699 & 0.06707 \\
\hline & Midilli et al. & 0.9888 & 0.01204 & 0.04147 \\
\hline & Modified Midilli et al. & 0.9888 & 0.01378 & 0.04150 \\
\hline \multirow{7}{*}{$15 \% E A+10 \% W P I-5 m$} & Lewis & 0.9734 & 0.03667 & 0.06383 \\
\hline & Page & 0.9888 & 0.01378 & 0.04150 \\
\hline & Henderson \& Pabis & 0.9717 & 0.03467 & 0.06583 \\
\hline & Logarithmic & 0.9709 & 0.03570 & 0.06680 \\
\hline & Two-term & 0.9706 & 0.02700 & 0.06709 \\
\hline & Midilli et al. & 0.9888 & 0.01204 & 0.04147 \\
\hline & Modified Midilli et al. & 0.9888 & 0.01378 & 0.04150 \\
\hline \multirow{7}{*}{$15 \% E A+10 \% W P I-6 \mathrm{~mm}$} & Lewis & 0.9737 & 0.03629 & 0.06350 \\
\hline & Page & 0.9861 & 0.01704 & 0.04615 \\
\hline & Henderson \& Pabis & 0.9717 & 0.03467 & 0.06583 \\
\hline & Logarithmic & 0.9734 & 0.03264 & 0.06387 \\
\hline & Two-term & 0.9706 & 0.02699 & 0.06707 \\
\hline & Midilli et al. & 0.9888 & 0.01204 & 0.04147 \\
\hline & Modified Midilli et al. & 0.9888 & 0.01378 & 0.04150 \\
\hline
\end{tabular}


Table 3. Statistical results of tested models for drying at $60^{\circ} \mathrm{C}$.

\begin{tabular}{|c|c|c|c|c|}
\hline Sample- thickness & Model & Adj- $R^{2}$ & SSE & RMSE \\
\hline \multirow{7}{*}{ Control-2.5 mm } & Lewis & 0.9583 & 0.05841 & 0.08056 \\
\hline & Page & 0.9877 & 0.01534 & 0.04379 \\
\hline & Henderson \& Pabis & 0.9611 & 0.04850 & 0.07786 \\
\hline & Logarithmic & 0.9611 & 0.04850 & 0.07786 \\
\hline & Two-term & 0.9481 & 0.04850 & 0.08991 \\
\hline & Midilli et al. & 0.9892 & 0.01183 & 0.04111 \\
\hline & Modified Midilli et al. & 0.9877 & 0.01534 & 0.04379 \\
\hline \multirow{7}{*}{ Control-3.2 mm } & Lewis & 0.9476 & 0.08417 & 0.09174 \\
\hline & Page & 0.9873 & 0.01834 & 0.04514 \\
\hline & Henderson \& Pabis & 0.9519 & 0.06954 & 0.08790 \\
\hline & Logarithmic & 0.9519 & 0.06954 & 0.08790 \\
\hline & Two-term & 0.9381 & 0.06955 & 0.09968 \\
\hline & Midilli et al. & 0.9900 & 0.01279 & 0.03998 \\
\hline & Modified Midilli et al. & 0.9873 & 0.01834 & 0.04514 \\
\hline \multirow{7}{*}{$15 \% E A-5 \mathrm{~mm}$} & Lewis & 0.9516 & 0.05243 & 0.09347 \\
\hline & Page & 0.9940 & 0.00498 & 0.03304 \\
\hline & Henderson \& Pabis & 0.9506 & 0.04465 & 0.09450 \\
\hline & Logarithmic & 0.9438 & 0.05079 & 0.10080 \\
\hline & Two-term & 0.9176 & 0.04465 & 0.12200 \\
\hline & Midilli et al. & 0.9945 & 0.00437 & 0.03154 \\
\hline & Modified Midilli et al. & 0.9945 & 0.00498 & 0.03154 \\
\hline \multirow{7}{*}{$15 \% E A-6 m m$} & Lewis & 0.9671 & 0.04077 & 0.07630 \\
\hline & Page & 0.9981 & 0.00203 & 0.01840 \\
\hline & Henderson \& Pabis & 0.9616 & 0.04075 & 0.08241 \\
\hline & Logarithmic & 0.9786 & 0.02272 & 0.06154 \\
\hline & Two-term & 0.9711 & 0.03065 & 0.07150 \\
\hline & Midilli et al. & 0.9983 & 0.00176 & 0.01717 \\
\hline & Modified Midilli et al. & 0.9983 & 0.00177 & 0.01877 \\
\hline \multirow{7}{*}{$15 \% E A+10 \% W P I-5 \mathrm{~mm}$} & Lewis & 0.9806 & 0.02246 & 0.05664 \\
\hline & Page & 0.9974 & 0.00260 & 0.02195 \\
\hline & Henderson \& Pabis & 0.9879 & 0.01200 & 0.04472 \\
\hline & Logarithmic & 0.9860 & 0.01387 & 0.04809 \\
\hline & Two-term & 0.9663 & 0.02231 & 0.07468 \\
\hline & Midilli et al. & 0.9974 & 0.00241 & 0.02082 \\
\hline & Modified Midilli et al. & 0.9970 & 0.00296 & 0.02219 \\
\hline \multirow{7}{*}{$15 \% E A+10 \% W P I-6 \mathrm{~mm}$} & Lewis & 0.9706 & 0.04013 & 0.07082 \\
\hline & Page & 0.9973 & 0.00320 & 0.02153 \\
\hline & Henderson \& Pabis & 0.9726 & 0.03270 & 0.06835 \\
\hline & Logarithmic & 0.9783 & 0.02589 & 0.06082 \\
\hline & Two-term & 0.9697 & 0.02590 & 0.07197 \\
\hline & Midilli et al. & 0.9975 & 0.00256 & 0.02071 \\
\hline & Modified Midilli et al. & 0.9975 & 0.00300 & 0.02081 \\
\hline
\end{tabular}


Table 4. Statistical results of tested models for drying at $70^{\circ} \mathrm{C}$.

\begin{tabular}{|c|c|c|c|c|}
\hline Sample- thickness & Model & Adj- $R^{2}$ & SSE & RMSE \\
\hline \multirow{7}{*}{ Control-2.5 mm } & Lewis & 0.9660 & 0.04750 & 0.07705 \\
\hline & Page & 0.9966 & 0.00421 & 0.02451 \\
\hline & Henderson \& Pabis & 0.9688 & 0.03815 & 0.07383 \\
\hline & Logarithmic & 0.9688 & 0.03815 & 0.07383 \\
\hline & Two-term & 0.9636 & 0.03815 & 0.07974 \\
\hline & Midilli et al. & 0.9966 & 0.00365 & 0.02447 \\
\hline & Modified Midilli et al. & 0.9966 & 0.00421 & 0.02451 \\
\hline \multirow{7}{*}{ Control-3.2 mm } & Lewis & 0.9556 & 0.06283 & 0.08862 \\
\hline & Page & 0.9951 & 0.00609 & 0.02950 \\
\hline & Henderson \& Pabis & 0.9624 & 0.04648 & 0.08149 \\
\hline & Logarithmic & 0.9624 & 0.04648 & 0.08149 \\
\hline & Two-term & 0.9562 & 0.04648 & 0.08802 \\
\hline & Midilli et al. & 0.9953 & 0.00503 & 0.02897 \\
\hline & Modified Midilli et al. & 0.9951 & 0.00605 & 0.02940 \\
\hline \multirow{7}{*}{$15 \% E A-5 \mathrm{~mm}$} & Lewis & 0.9720 & 0.02313 & 0.06802 \\
\hline & Page & 0.9945 & 0.00365 & 0.03019 \\
\hline & Henderson \& Pabis & 0.9731 & 0.01782 & 0.06675 \\
\hline & Logarithmic & 0.9731 & 0.01782 & 0.06675 \\
\hline & Two-term & 0.9462 & 0.01782 & 0.09440 \\
\hline & Midilli et al. & 0.9952 & 0.002371 & 0.02811 \\
\hline & Modified Midilli et al. & 0.9950 & 0.003306 & 0.02875 \\
\hline \multirow{7}{*}{$15 \% E A-6 m m$} & Lewis & 0.9509 & 0.04271 & 0.09243 \\
\hline & Page & 0.9905 & 0.00662 & 0.04067 \\
\hline & Henderson \& Pabis & 0.9385 & 0.04286 & 0.10350 \\
\hline & Logarithmic & 0.9351 & 0.04523 & 0.10630 \\
\hline & Two-term & 0.9457 & 0.03785 & 0.09727 \\
\hline & Midilli et al. & 0.9915 & 0.00440 & 0.03840 \\
\hline & Modified Midilli et al. & 0.9905 & 0.00662 & 0.04070 \\
\hline \multirow{7}{*}{$15 \% E A+10 \% W P I-5 m$} & Lewis & 0.9491 & 0.04307 & 0.09357 \\
\hline & Page & 0.9945 & 0.00377 & 0.03070 \\
\hline & Henderson \& Pabis & 0.9539 & 0.03171 & 0.08904 \\
\hline & Logarithmic & 0.9438 & 0.03866 & 0.09831 \\
\hline & Two-term & 0.9412 & 0.04044 & 0.10050 \\
\hline & Midilli et al. & 0.9952 & 0.00330 & 0.02870 \\
\hline & Modified Midilli et al. & 0.9947 & 0.00360 & 0.03010 \\
\hline \multirow{7}{*}{$15 \% E A+10 \% W P I-6 m m$} & Lewis & 0.9636 & 0.03122 & 0.07901 \\
\hline & Page & 0.9963 & 0.00190 & 0.02506 \\
\hline & Henderson \& Pabis & 0.9539 & 0.03168 & 0.08900 \\
\hline & Logarithmic & 0.9615 & 0.02644 & 0.08130 \\
\hline & Two-term & 0.9505 & 0.03396 & 0.09214 \\
\hline & Midilli et al. & 0.9966 & 0.00188 & 0.02400 \\
\hline & Modified Midilli et al. & 0.9961 & 0.00270 & 0.02590 \\
\hline
\end{tabular}


Table 5. Model constants of the best fitting theoretical model.

\begin{tabular}{|c|c|c|}
\hline Temperature $\left({ }^{\circ} \mathrm{C}\right)$ & Sample & Midilli et al. model constant \\
\hline 50 & $\begin{array}{l}\text { Control-2.5 mm } \\
\text { Control-3.2 } \mathrm{mm}\end{array}$ & $\begin{array}{l}a=0.932, b=2.338 * 10^{-14}, k=0.0003, n=1.556 \\
a=0.943, b=3.185 * 10^{-12}, k=0.0001, n=1.659\end{array}$ \\
\hline 60 & $\begin{array}{l}\text { Control-2.5 mm } \\
\text { Control-3.2 mm }\end{array}$ & $\begin{array}{l}a=0.953, b=2.223 * 10^{-14}, k=0.0005, n=1.659 \\
a=0.947, b=4.233 * 10^{-10}, k=0.0002, n=1.859\end{array}$ \\
\hline 70 & $\begin{array}{l}\text { Control-2.5 mm } \\
\text { Control-3.2 } \mathrm{mm}\end{array}$ & $\begin{array}{l}a=0.978, b=1.943 * 10^{-12}, k=0.0021, n=1.626 \\
a=0.973, b=2.332 * 10^{-14}, k=0.0009, n=1.682\end{array}$ \\
\hline 50 & $\begin{array}{l}15 \% E A-5 \mathrm{~mm} \\
15 \% E A-6 \mathrm{~mm}\end{array}$ & $\begin{array}{l}a=0.962, b=2.244 * 10^{-14}, k=0.0029, n=1.363 \\
a=0.962, b=2.309 *^{*} 10^{-14}, k=0.0028, n=1.363\end{array}$ \\
\hline 60 & $\begin{array}{l}15 \% E A-5 \mathrm{~mm} \\
15 \% E A-6 \mathrm{~mm}\end{array}$ & $\begin{array}{l}a=0.977, b=1.189 * 10^{-9}, k=0.0014, n=1.874 \\
a=1.002, b=2.256 * 10^{-14}, k=0.0036, n=1.536\end{array}$ \\
\hline 70 & $\begin{array}{l}15 \% E A-5 \mathrm{~mm} \\
15 \% E A-6 \mathrm{~mm}\end{array}$ & $\begin{array}{l}a=1.000, b=2.417^{*} 10^{-14}, k=0.0012, n=1.502 \\
a=0.999, b=4.348 * 10^{-14}, k=0.0006, n=2.203\end{array}$ \\
\hline 50 & $\begin{array}{l}15 \% E A+10 \% W P I-5 \mathrm{~mm} \\
15 \% E A+10 \% W P I-6 \mathrm{~mm}\end{array}$ & $\begin{array}{l}a=0.962, b=1.559 * 10^{-11}, k=0.0028, n=1.363 \\
a=0.962, b=2.222 * 10^{-14}, k=0.0029, n=1.363\end{array}$ \\
\hline 60 & $\begin{array}{l}15 \% E A+10 \% W P I-5 \mathrm{~mm} \\
15 \% E A+10 \% W P I-6 \mathrm{~mm}\end{array}$ & $\begin{array}{l}a=0.999, b=2.245^{*} 10^{-14}, k=0.0069, n=1.354 \\
a=0.994, b=2.221 * 10^{-14}, k=0.0036, n=1.444\end{array}$ \\
\hline 70 & $\begin{array}{l}15 \% E A+10 \% W P I-5 \mathrm{~mm} \\
15 \% E A+10 \% W P I-6 \mathrm{~mm}\end{array}$ & $\begin{array}{l}a=0.986, b=2.220 * 10^{-14}, k=0.0034, n=1.657 \\
a=0.997, b=2.221 * 10^{-14}, k=0.0048, n=1.596\end{array}$ \\
\hline
\end{tabular}

Since carrot juice is a valuable source of carotenoids, the encapsulation of these bioactive compounds with wall materials including the proteins or stabilizers by foam-mat drying like this present study will promote longer stability of carotenoids [28]. Therefore, the efforts related with finding better drying conditions in terms of selecting different dryers such as non-thermal or hybrid dryers together with modifying the drying temperature and air velocity will help to provide an insight for further foam-mat drying of similar juices.

\section{CONCLUSION}

It has been determined that the foam-mat drying process shortens the drying time of carrot juice by $25-60 \%$ depending on the drying temperature and the foam thickness. These results in accordance with the effective diffusion coefficients, since the drying of foamed juices had higher $D_{\text {eff }}$ values compared to the control sample.

Consequently, the compatibility of experimental drying data of carrot juice with the tested theoretical models was evaluated, and the adjusted correlation coefficients of the tested theoretical models varied between 0.93-0.99, which showed that the fitted models had a high ability to represent the drying behavior of the carrot juice, 15\% EA and 15\% EA+ 10\% WPI foams. However, among these mo- dels, regardless of the foam composition, drying temperature, or foam thicknesses, the best results were found with the Midilli et al. model. Future studies may focus on prediction of the drying data of different fruit juice foams by the same theoretical model.

\section{ACKNOWLEDGEMENT}

This work was supported by the Hitit University Scientific Research Commission through a research Grant No. MUH19001.18.002.

\section{CONFLICT OF INTEREST}

The authors declare that there is no conflict of interest.

\section{AUTHOR CONTRIBUTION}

Hülya Çakmak: Funding acquisition, Formal analysis, Investigation, Conceptualization, Methodology, Writing - original draft, Writing - review \& editing. V. Hazal Özyurt: Formal analysis, Conceptualization, Investigation, Methodology, Writing - original draft, Writing - review \& editing. Both authors read and approved the final manuscript. 


\section{References}

1. Amit SK, Uddin MM, Rahman R, Islam SR, Khan MS. A review on mechanisms and commercial aspects of food preservation and processing. Agriculture \& Food Security 6(1) (2017) 1-22

2. Kumar C, Karim MA, Joardder MU. Intermittent drying of food products: A critical review. Journal of Food Engineering 121 (2014) 48-57.

3. Nindo CI, Tang J. Refractance window dehydration technology: a novel contact drying method. Drying Technology 25(1) (2007) 37 48.

4. Castro AM, Mayorga, EY, Moreno FL. Mathematical modelling of convective drying of fruits: A review. Journal of Food Engineering 223 (2018) 152-167.

5. Nathakaranakule A, Jaiboon P, Soponronnarit S. Far-infrared radiation assisted drying of longan fruit. Journal of Food Engineering 100(4) (2010) 662-668.

6. Duan X, Yang X, Ren G, Pang Y, Liu L, Liu Y. Technical aspects in freeze-drying of foods. Drying Technology 34(11) (2016) 1271-1285.

7. Pan YK, Zhao LJ, Zhang Y, Chen G, Mujumdar AS. Osmotic dehydration pretreatment in drying of fruits and vegetables. Drying Technology 21(6) (2003) 1101-1114.

8. Cakmak H. Evaluation of foam-mat drying behaviour of crab apple (Malus floribunda) fruit juice and powder quality. G1da 45(3) (2020) 530-543.

9. Falade KO, Onyeoziri NF. Effects of cultivar and drying method on color, pasting and sensory attributes of instant yam (Dioscorea rotundata) flours. Food and Bioprocess Technology 5(3) (2012) 879-87.

10. Thuwapanichayanan R, Prachayawarakorn S, Soponronnarit S Drying characteristics and quality of banana foam mat. Journal of Food Engineering 86(4) (2008) 573-583.

11. De Barros Fernandes RV, Queiroz F, Botrel DA, Rocha VV, Lima CF, Souza VR. Foam mat drying of tomato pulp. Bioscience Journal Uberlandia 29(4) (2013) 816-825.

12. Zheng $\mathrm{XZ}$, Liu $\mathrm{CH}$, Zhou H. Optimization of parameters for microwave-assisted foam mat drying of blackcurrant pulp. Drying Technology 29(2) (2011) 230-238.

13. Ibidapo OP, Erukainure OL. Quality characteristics of foam mat dried papaya (Homestead var.) nectar. International Journal of Food Nutrition and Safety 1(3) (2012) 127-136.

14. Kadam DM, Wilson RA, Chanha S, Grewal MK, Sharma M. Evaluation of physical and chemical properties of foam-mat dried mango (Mangifera indica) powder during storage. Journal of Food Processing Preservation 38 (2014) 1866-1874.

15. Asokapandian S, Venkatachalam S, Swamy GJ, Kuppusamy K. Optimization of foaming properties and foam mat drying of muskmelon using soy protein. Journal of Food Process Engineering 39(6) (2016) 692-701
16. Franco TS, Perussello CA, Ellenderse LN, Masson ML. Effects of foam mat drying on physicochemical and microstructural properties of yacon juice powder. LWT-Food Science Technology 66 (2016) 503-513.

17. Kartini K, Krisnawan AH, Silvanus LC, Wijaya TP. Formulation of functional beverages from the combination of lime, tomato, and carrot using foam-mat drying method. Pharmaciana 9(2) (2019) 335-344.

18. Fardiyah Q, Rumhayati B, Khotimah YH. The effect of temperature and concentration of foaming agent to the $\beta$-carotene content in product derived from carrots. In IOP conference series: Materials Science and Engineering 299(1) (2018) 012008. IOP Publishing.

19. Cakmak H, Ozyurt VH. Foam stability of cloudy carrot juice: Effects of protein sources and foaming conditions. The Annals of the University of Dunarea de Jos of Galati. Fascicle VI. Food Technology 45(1) (2021) 38-51.

20. Demir N, Bahçeci KS, Acar J. The effect of processing method on the characteristics of carrot juice. Journal of Food Quality 30(5) (2007) 813-822

21. Kucuk H, Midilli A, Kilic A, Dincer I. A review on thin-layer drying-curve equations. Drying Technology, 32(7) (2014) 757-773.

22. Dehghannya J, Pourahmad M, Ghanbarzadeh B, Ghaffari H. Influence of foam thickness on production of lime juice powder during foam-mat drying: experimental and numerical investigation. Powder Technology 328 (2018) 470-484.

23. Chaux-Gutiérrez AM, Santos AB, Granda-Restrepo DM, Mauro MA. Foam mat drying of mango: Effect of processing parameters on the drying kinetic and product quality. Drying Technology 35(5) (2017) 631-641.

24. Kudra T, Ratti C. Foam-mat drying: Energy and cost analyses. Canadian Biosystems Engineering 48(3) (2006) 27-32.

25. Hardy Z, Jideani VA. Foam-mat drying technology: A review. Critical Reviews in Food Science and Nutrition 57(12) (2017) 25602572 .

26. Abbasi E, Azizpour M. Evaluation of physicochemical properties of foam mat dried sour cherry powder. LWT-Food Science and Technology 68 (2016) 105-110.

27. Seerangurayar T, Manickavasagan A, Al-Ismaili AM, Al-Mulla YA. Effect of carrier agents on flowability and microstructural properties of foam-mat freeze dried date powder. Journal of Food Engineering 215 (2017) 33-43.

28. Haas K, Dohnal T, Andreu P, Zehetner E, Kiesslich A, Volkert M, Fryer P, Jaeger H. Particle engineering for improved stability and handling properties of carrot concentrate powders using fluidized bed granulation and agglomeration. Powder Technology 370 (2020) 104-115. 